\title{
Impacts of Louisiana Public Policy on Employment: An Econometric Analysis
}

\author{
Russell M. Frazier, Ph.D. \\ Department of Political Science, \\ Xavier University, New Orleans, Louisiana
}

\begin{abstract}
Employment plays a key role in the growth and development of any state economy, particularly given its potential to affect the standards of living for the population, as well as the revenues and expenditure of the government itself. A disaggregated evaluation of employment growth enables stakeholders to engage public policy formation in a more effective and efficacious manner. Therefore, the primary goal of this paper is to analyze employment growth trends and policy implications relative to the economic development of Louisiana's industries at the sector level, by employing a rigorous shift-share analysis. The research employs data for twelve years from 2005 to 2017 to answer the guiding questions of this applied empirical research. Results show that comparative advantages are seen in the following areas: Finance and Insurance; Real Estate and Rental and Leasing; Administrative and Waste Services; Educational Services; Accommodation and Food Services; and Other Services (except for Public Administration). Thus, program initiatives directed at those sectors, with sufficient infrastructure, would enhance the economic development of Louisiana. It is plausible to believe that improved economic growth would draw new investors to Louisiana.
\end{abstract}

Keywords: Public Policy, Political Economy, Econometrics, Shift-Share, Policy Formation, Policy Implementation, Workforce Development, Community Economics, Louisiana

\section{INTRODUCTION}

Regional economies often rely on employment growth to maintain its economic stability (Lapping, 2006; Knudsen, 2000). Thus, policymakers at the federal, state and local level seek to create policy alternatives that attract new investment. Nevertheless, it is imperative that policy actors understand how all economic sectors factor into the comparative advantage of a given context. Understanding the aforesaid dynamics of Louisiana industry enable policymakers to grow their economy by developing more efficacious and effective policy initiatives (Melachroinos, 2002).

The recognition of how competitiveness factors and industry mix impact a regional economy is especially important when considering states like Louisiana. Louisiana is an economically challenged state that seems to continuously engage in Sisyphean economic endeavors. The total population of Louisiana was 4,659,978 in 2018, of which 84 percent of Louisianans resided within metropolitan counties and the remaining 16 percent lived in rural counties (USDA-ERS, 2019). In 2017, Louisiana recorded the second highest poverty rate in the country at 19.7 percent (USCB, 2018). Additionally, Louisiana's poverty rate was 7.4 percent higher than the 12.3 percent national average (USCB, 2018). And according to the Bureau of Labor Statistics (2019), Louisiana's unemployment rate peaked at 11.5 percent in September 2005 and was only 6.6 percent lower in January 2019 (BLS, 2005 \& 2019).

The average per capita income in Louisiana was \$26,205 in 2017 (USCB, 2018). Louisiana's median household income in 2017 was $\$ 46,710$, falling $\$ 10,942$ short of the $\$ 57,652$ national 
average (USCB, 2018). Health Care and Social Assistance; Retail Trade; Accommodation and Food Services are the main employment industries in Louisiana. However, in terms of state GDP, Louisiana boasts a healthy agricultural sector, where it stands as one of the nation's largest producers of sugar cane and cotton (Louisiana Division of Administration, 2019). Louisiana also ranks second in US oil production. The state holds nearly 10 percent of the United States' oil reserves. While the said factors contribute heavily to the State's economic vitality, forestry endures as the leading industry in the State followed by tourism (Louisiana Division of Administration, 2019). That is, most of the State's revenue is generated by a combination of sub-sectors (i.e., lumber, furniture, and pulp and paper) within the forest industry. Furthermore, tourism factors such as "hotel room-nights sold, including those for conventions, airport passengers, and tourism employment added substantial revenue to the State" (Ortiz, 2016, p. 9). So, the primary aim of this paper is to analyze employment growth trends and policy implications relative to the economic development of Louisiana's industries at the sector level, by employing a rigorous shift share analysis. More pointedly, the study answers multiple causal questions: What policy interventions bolster economic prosperity and how do we utilize rigorous conceptual measures to adequately depict the impact of policy alternatives? In order to answer these questions, we will need to establish an operational definition of economic development as it pertains to governments at the regional, or state level. I'll subscribe to the following: Economic development encompasses the formation of additional industries and growth of existing industries, in a way that increases employment opportunities and steadily influences the increase of the average income (Brown, H.J., 1969).

In the subsequent segment, this study offers contextual information concerning the impact of policy on employment based on the relevant literature. Next, the study describes shift-share analysis and data sources. Analysis and outcomes are presented in the following segment. The last section provides a summary of results and policy implications.

\section{IMPACTS OF POLICY ON EMPLOYMENT}

Employment plays a key role in the growth and development of any country, particularly given its potential to affect the standards of living for the population, as well as the revenues and expenditure of the government itself. Of note, is the fact that employment is a function of the environment within which it is created. Indeed, there are varying factors that have a bearing on the employment levels and dynamics in any country, key among them are the policies that have been put in place. Volumes of literary works have examined the effects of government policies on the employment levels in a country. The proceeding review provides contextual information concerning the impact of policy on employment based on the relevant literature.

According to Pestel (2014), policies determine the areas in which the government will be investing or dedicating its expenditure. This comes to the forefront particularly with regard to the green energy policies that have been put in place by varying countries. That is, a large number of European countries have indicated their commitment to the achievement of the 20$20-20$ targets where they will reduce their greenhouse gas emissions by $20 \%$ by 1990 , increase by $20 \%$ the amount of energy consumption from renewable energy sources and enhance energy efficiency by $20 \%$ by 2020 . The energy turnaround in Germany, which is the largest economy in Europe, means that the government would replace its nuclear plants with renewable energy sources. Such changes towards low-carbon economies necessitate immense investments in green energy technologies. Further, the green energy industries must be boosted and regulated given the fact that they are not cost-effective particularly in the formative years. This triggers subsidies to the industry so that the government can boost or stimulate the expansion of the industries' renewable energy sources through the provision of feed-in tariffs. These subsidies would have the effect of stimulating or boosting the aggregate 
demand for development and research, production, as well as the maintenance and installation of the various green energy technologies. In essence, it would increase employment through the creation of new jobs or employment opportunities.

Nevertheless, policies that are supposed to generate positive effects for the economy could have unintended negative impacts. This hinges on the effects of existing programs on the current economic sectors. For example, as much as the expansion of green energy could benefit labor productivity, quality of the environment and overall health, it is important to mention that policies and programs that are financed by feed-in tariffs could have a contrary effect on the other industries (Martin, 2014). For instance, the implementation of tariffs to enhance growth in the green energy sector might require an increase in the price of energy for private households and business entities to give incentives for them to shift to green energy sources. In essence, it may be argued that such policies, while increasing the employment levels in the green energy sector, could also be putting energy-intensive manufacturing and industrial sectors at risk especially in cases where their products and services target the export market and where international competitors have considerably lower costs of energy.

However, it is imperative that the effectiveness of government policies, or the magnitude of its impacts is predicated on the target market. Toshkov and Haan, D. (2013), expressed that government policies that stimulate the growth of small and medium enterprises (SMEs) would be more beneficial, as far as enhancing employment is concerned, compared to those that target large scale industries. These policy efforts are particularly focused on the elasticity of the small and medium enterprises compared to that of large-scale industries. It is imperative to point out that large scale industries often specialize in distinctive areas of expertise where they can only employ a limited number of people. Further, large scale industries often have rigid structures that make it difficult for them to venture into other regions, or even other industries unlike small and medium enterprises that often do not have many impediments pertaining to the industry within which they can venture, or even the region where they establish their operations. Additionally, small and medium enterprises have been responsible for over 50 percent of the total employment in varying countries including Canada and Nigeria.

Similarly, it is noteworthy that the policies that are put in place would have a positive effect on the timeline being examined. Card and Weber (2010), reported that any consideration regarding the effectiveness of active labor market policies must consider the appropriateness of the policies in the short-term and the long-term. It is essential that employment service policies have positive effects in the short-term, while policies that imbue training programs in an organization are more appropriate for the long-term. It is also advantageous to develop and implement long-term policies that focus on enhancing the availability of effective labor. The crucial nature of targets pertaining to active labor market policies is heightened in the context of long-term employment, which would be affected by the timelines or duration, as well as the implementation levels for the new instruments of the policy.

Furthermore, the potential for individuals to enter a particular industry could be significantly influenced by the government policies. A study conducted by Van and Koster (2011), found that variations in labor market policies, economic conditions, and education could create systematic cross-country variations in the opportunities for youth to gain access to the labor market. Youths or individuals from nations that were adversely affected by the economic crisis and are plagued by structurally low demand for labor, have a higher potential for long-term unemployment. There is a close relationship between labor market policies, particularly those touching on minimum wage or hiring policies, and the levels of youth employment. Such policies also have a bearing on the general schooling system thereby determining not only the 
amount and type of skill that is available in the market, but also the potential for them to access industry and gain employment.

Moreover, policy decisions could affect the attractiveness of organizations to specific talents. According to Al-Anzi (2009), different countries have varying policies that have a bearing on employee relations in the long-term and the short-term and the attractiveness of particular industries. For instance, countries such as the United States have strict and comprehensive laws and regulations pertaining to labor relations, as well as the manner in which employees should be treated. Employees are offered protections that would have a bearing on the attractiveness of the industries themselves and the capacity of the country to attract investors. In the last two decades, a large proportion of American companies have been relocating most of their operations to China, which has fewer and less stringent regulations, as well as less powerful labor unions. This means that the varying business entities can offer substandard wages to employees and, essentially, maximize their profits in the long-term and the shortterm. This demonstrates the fact that government policies could affect the employment rates, in a country, based on its impacts on the profitability of corporate entities, particularly with regard to laws and regulations that touch on employee relations and labor.

Equally, the type of market on which the policies are applied influences the effects that they have on employment itself. Rueda (2006), argued that in cases where there is heightened internationalization of capital, governments are limited in applying social democracy, as it constrains the capacity of the government to promote equality, growth and employment. The market environment within which the policies are applied determines other factors that could have a bearing on the effectiveness of any policy in achieving the required, or stipulated goals.

On the same note, the environment determines the other factors that would interact with the policy in the course of its implementation to determine how it impacts the society at large. Active labor market policies, on the other hand, are supply side policies that partisan governments could utilize for stimulation of equality, growth and employment in environments that are impacted highly by globalism. Even more substantial is the fact that social democratic governments have the capacity to safeguard and stimulate interests of labor, while conservative ones seek to meet demands pertaining to upscale groups. In such circumstances, labor is perceived as being disproportionately affected by unemployment, while social democratic governments would be likely to organize political platforms and come up with policies that stimulate labor support through lowering unemployment. This means that the business and political environment within which policies are implemented would have a bearing on their effects and impacts in the long-term and the short-term.

Also, macroeconomic policies could have a bearing on the availability of labor in a country. For instance, research results show that migrant workers usually have significant economic disadvantages compared to the native population, an element that maybe attributed to the social demographic background such as country of birth, ethnicity, marital status, age, gender and education, as well as other attributes such as language skills and length of time they have stayed in the host country (Cangiano, 2014). It is well documented that the immigration policies of any country are primarily aimed not only at controlling the type of people who get into a country, but also safeguard the country's economic advantages. This explains why some people have an easier process entering a country compared to other people. Immigrants who enter another country through the labor immigration channels often have systematically higher employment rates compared to the domestic workforce. Conversely, family and humanitarian immigrants have decreased opportunity for employment, particularly in European countries. This may be because they have less capacity to obtain the necessary 
academic credentials for the acquisition of jobs, not to mention the fact that humanitarian immigrants are often restricted to areas where they would be offered the assistance that they need. Similarly, most countries have policies that promote the employment and preference for indigenous populations, particularly in cases where the skills required are available in the local populace. Also, migrant populations usually are not allowed to vote, thus, the indigenous populations have more political sway pertaining to their potential for gaining employment in the long-term and the short-term. Nevertheless, once the non-economic immigrants have settled in the host countries, many of them look for and find employment. This may be based on the fact that they may have created and established networks with the local populace, or even learned their language, which enhances their suitability for the jobs. Even more considerable is the fact that in some cases, the restrictive policies to employment of immigrants could be resulting in a waste of skills and talents. That is, it is common that migrants have a higher likelihood than domestic workers to be overqualified for the positions or jobs that are available to them. The focus on formal qualifications as the main selection criteria that would optimize migrant social economic integration could also be insufficient, given that skill-selected migrants often work in low-skilled jobs. Of course, there are significant gender differences in the over-qualification of immigrants. For example, most women migrate to other countries on non-economic grounds, where they follow their spouses to other countries. In most cases, they end up not having jobs, although they are significantly qualified for technical jobs. However, as stated above, they could move into highly skilled jobs as they establish professional and social networks, learn the host country's language and determine a clear line of career progression.

Lastly, it is imperative that one acknowledges the fact that there are distinctive laws that have a bearing on the employment levels and employment shifts in a country that is devastated by experiencing natural disasters. The New Zealand Health and Safety at Work Act (2015), states that business entities have a responsibility to put in place procedures, including the emergency response plan, that should be adhered to in case an emergency comes up. Once a natural disaster occurs, employers are required to determine the entitlements of the employees particularly in cases where they are forced to close the facilities because of natural disasters. These could include providing the option of taking accrued paid leave or even furlough the employees. Employers can apply the above options in cases where there exist no useful tasks for them to carry out, which could occur in cases where the basis for employee dismissal is beyond the control of the employer as is the case for natural disasters. Furloughs may be unpaid although employers may decide to pay their employees (Loayza et al., 2009). Evidently, such laws have a bearing on employment shifts particularly in the case of natural disasters. Subject to the magnitude of the natural disaster, the timing and level of devastation, there is a high possibility that businesses would be forced to close for a long time. For instance, during hurricane Katrina, neighborhoods remained closed for weeks as the water slowly subsided. This meant that businesses remained closed, not to mention the fact that people could not access them (Loayza et al., 2009). Additionally, infrastructure had broken down significantly, while people were forced to flee from their homes. This caused significant impediments to the flow of commerce, with some entities incurring heavy losses. As much as some businesses were unable to recover from the disaster, the rebuilding process increased employment in the affected areas as the State and local governments had to inject significant amounts of funds to assist in the restoration of the city.

\section{Shift-Share Methodology}

\section{SHIFT-SHARE ANALYSIS AND DATA SOURCES}

The purpose of this shift-share analysis is to perform a numerical sort on the data that offers a construct for describing key differences between the growth of employment in Louisiana and 
the nation at large. Specifically, this shift-share study analyzes the longitudinal employment shifts in Louisiana between 2005 and 2017. The analysis depicts the differences between the extent and composition of local employment growth with comparison to the nation and is broken down into three components (Bendavid-Val, A., 1983; Hustedde, R. et al., 1989):

(1) A National Growth effect, which is that part of the change in total employment in a region ascribed to the rate of growth of employment in the nation as a whole. The National Growth $\left(\mathrm{NG}_{\mathrm{i}}\right)$ component for subtotal is computed as the product of employment in subtotal for the beginning year (2005), e.g., (i.e., $\left.E_{i}, 2005=832,721\right)$, and the overall growth rate of employment nationally over 2005-2017(13.81\%).

(2) An Industry Mix effect, which is the amount of change the region would have experienced had each of its industries grown at their national rates, less the national growth effect. The Industry Mix $\left(\mathrm{IM}_{\mathrm{i}}\right)$ component is calculated by multiplying local subtotal employment in the beginning year (2005), (i.e., $\mathrm{E}_{\mathrm{i},}, 2005=832,721$ ), by the difference in the national growth rate for subtotal employment $(21.50 \%)$ and the national growth rate for total employment (13.81\%).

(3) A Regional Shift or Competitive effect, which is the difference between the actual change in employment and the employment change to be expected if each industrial sector grew at the national rate. The sum of these three effects equals the actual change in total employment within a region over a prescribed period. The Regional Shift (RSi) component is computed by multiplying local subtotal employment in the beginning year (2005), (i.e., $E_{\mathrm{i}}, 2005=832,721$ ), by the difference in Louisiana's growth rate for subtotal employment $(0.00 \%)$ and the growth of subtotal nationally $(21.50 \%)$.

Utilizing a rigorous shift-share analysis to assess twelve years (2005-2017) of employment data in Louisiana qualifies this research as an inimitable study. The primary employment sectors of Louisiana namely Health Care and Social Assistance, Retail Trade, Accommodation and Food Services are analyzed to evaluate the impact of State policy during the established time frame. The paper focuses on the sectors that would logically contribute to rapid economic growth in Louisiana.

\section{Data Sources}

This study utilizes national (USA) and State (LA) employment data collected by the United States Department of Commerce, Bureau of Economic Analysis between the years of 2005 and 2017 to make up shift-share components (see Tables 1, 2 and 3). The established parameters were set due to Louisiana's need to reposition itself economically after Hurricane Katrina. While this study does not intimately focus on the economic impacts of Katrina, it is still necessary to note uncontrollable external factors that may have contributed to baseline economic data.

\section{ANALYSIS AND OUTCOMES}

Figure 1. below depicts Louisiana employment expansion from 2005 to 2017 relative to the rest of the nation. Overall, eighteen states outpaced the national employment growth average of 13.81 percent, while thirty-three states underperformed. Louisiana is counted among those underachieving states; posting a 12.52 percent average. However, Louisiana fared better than thirty other states in the US. Nevertheless, the State's increase in employment still did not meet the 13.81 percent national average, thus registering a -1.29 percent comparative margin. This is a notable point of data in a shift-share analysis, as it indicates that employment issues exist within Louisiana. 


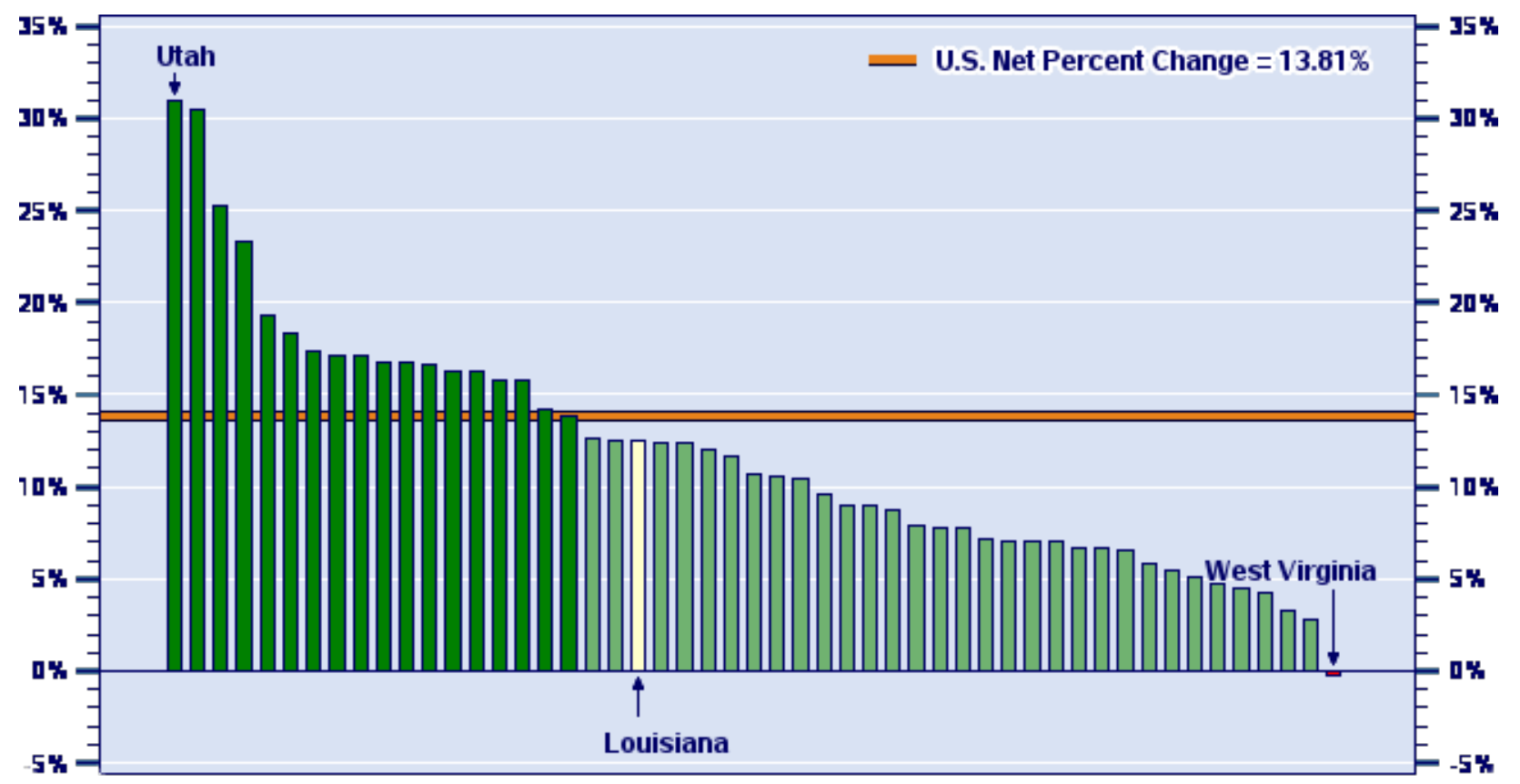

Figure.1 Employment Growth by State, 2005 vs. 2017, Net Percentage Change (Data: Regional Income Division, BEA, 2019)

The results of this shift-share analysis show that the Health Care and Social Assistance sector was the leading employment sector in 2005 and 2017 (Table 1.). During 2005 and 2017, more than 10 percent of all employees in Louisiana worked in the Health Care and Social Assistance sector. The retail trade sector reported the second largest number of employees; where it was also responsible for at least 10 percent of employment during both years. Next, Accommodation and Food Services ranked third, registering a 7.8 percent employment average for 2005 and 2017. Utilities suffered the lowest percentage of Louisiana's total employment at 0.4 percent.

According to Table 2 below, employment in the Health Care and Social Assistance sector increased at a rate of 34.85 percent nationally and 30.93 percent in Louisiana. The results also illustrate that employment in the Manufacturing sector, at both the State and national level, diminished during the twelve-year period. The employment rate in Local Government in Louisiana shows a downward trend, while the Local Government employment percentage at the national level is positive. This is simply representative of employment growth deficiencies at the State level juxtaposed to the Local Government employment growth at the national level from 2005 to 2017. Still, Construction; Accommodation and Food Services; Other Services (except Public Administration); Professional, Scientific, and Technical Services; and Administrative and Waste Services show positive employment growth in Louisiana and the United States. Both trends suggest that Louisiana should experience high growth in each of these respective sectors. Retail Trade; and Real Estate and Rental and Leasing reports greater employment increases in Louisiana compared to growth at the national level. 
Table 1: Louisiana Employment Growth 2005-2017

Employment (Employ)

\begin{tabular}{|c|c|c|c|c|c|c|c|c|c|}
\hline \multicolumn{5}{|c|}{ Employment (Employ) } & & & \multicolumn{3}{|c|}{ Standardized } \\
\hline & 201 & & 201 & & Actual & rowth & Growth ${ }^{2}$ & & Employ $^{3}$ \\
\hline $\begin{array}{l}\text { Major } \\
\text { Industry }\end{array}$ & Level & Share ${ }^{1}$ & Level & Share ${ }^{1}$ & Percent & Net & Percent & Net & 2017 \\
\hline $\begin{array}{l}\text { Farm } \\
\text { Employment }\end{array}$ & 30,001 & 1.3 & 31,641 & 1.2 & 5.47 & 1,640 & -0.94 & -282 & 29,719 \\
\hline $\begin{array}{l}\text { Forestry, } \\
\text { Fishing, and } \\
\text { Related } \\
\text { Activities }\end{array}$ & 18,662 & 0.8 & 18,579 & 0.7 & -0.44 & -83 & 11.70 & 2,183 & 20,845 \\
\hline Mining & 52,025 & 2.2 & 69,311 & 2.6 & 33.23 & 17,286 & 81.27 & 42,283 & 94,308 \\
\hline Utilities & 9,927 & 0.4 & 9,711 & 0.4 & -2.18 & -216 & 16.42 & 1,630 & 11,557 \\
\hline Construction & 175,340 & 7.3 & 206,448 & 7.7 & 17.74 & 31,108 & -3.02 & $-5,296$ & 170,044 \\
\hline Manufacturing & 157,479 & 6.6 & 145,660 & 5.4 & -7.51 & $-11,819$ & -9.64 & $-15,181$ & 142,298 \\
\hline $\begin{array}{l}\text { Wholesale } \\
\text { Trade }\end{array}$ & 79,437 & 3.3 & 76,086 & 2.8 & -4.22 & $-3,351$ & 2.28 & 1,811 & 81,248 \\
\hline Retail Trade & 260,099 & 10.8 & 278,508 & 10.3 & 7.08 & 18,409 & 2.98 & 7,753 & 267,852 \\
\hline $\begin{array}{l}\text { Transportation } \\
\text { and } \\
\text { Warehousing }\end{array}$ & 89,693 & 3.7 & 103,745 & 3.8 & 15.67 & 14,052 & 36.80 & 33,005 & 122,698 \\
\hline Information & 34,182 & 1.4 & 28,945 & 1.1 & -15.32 & $-5,237$ & -5.00 & $-1,711$ & 32,471 \\
\hline $\begin{array}{l}\text { Finance and } \\
\text { Insurance }\end{array}$ & 84,661 & 3.5 & 111,058 & 4.1 & 31.18 & 26,397 & 28.18 & 23,861 & 108,522 \\
\hline $\begin{array}{ll}\text { Real Estate and } \\
\text { Rental } & \text { and } \\
\text { Leasing } & \\
\end{array}$ & 82,356 & 3.4 & 120,261 & 4.5 & 46.03 & 37,905 & 28.09 & 23,132 & 105,488 \\
\hline $\begin{array}{l}\text { Professional, } \\
\text { Scientific, and } \\
\text { Technical } \\
\text { Services }\end{array}$ & 113,884 & 4.8 & 142,599 & 5.3 & 25.21 & 28,715 & 25.63 & 29,184 & 143,068 \\
\hline $\begin{array}{l}\text { Management of } \\
\text { Companies and } \\
\text { Enterprises }\end{array}$ & 23,059 & 1.0 & 30,477 & 1.1 & 32.17 & 7,418 & 43.39 & 10,006 & 33,065 \\
\hline \begin{tabular}{ll}
\multicolumn{2}{l}{ Administrative } \\
and & Waste \\
Services & \\
\end{tabular} & 130,569 & 5.4 & 151,855 & 5.6 & 16.30 & 21,286 & 16.20 & 21,148 & 151,717 \\
\hline $\begin{array}{l}\text { Educational } \\
\text { Services }\end{array}$ & 40,944 & 1.7 & 55,991 & 2.1 & 36.75 & 15,047 & 33.05 & 13,533 & 54,477 \\
\hline $\begin{array}{lr}\text { Health } & \text { Care } \\
\text { and } & \text { Social } \\
\text { Assistance } & \\
\end{array}$ & 240,449 & 10.0 & 314,821 & 11.7 & 30.93 & 74,372 & 31.87 & 76,619 & 317,068 \\
\hline $\begin{array}{l}\text { Arts, } \\
\text { Entertainment, } \\
\text { and Recreation }\end{array}$ & 49,070 & 2.0 & 54,032 & 2.0 & 10.11 & 4,962 & 28.87 & 14,168 & 63,238 \\
\hline $\begin{array}{lr}\text { Accommodation } \\
\text { and r Food } \\
\text { Services }\end{array}$ & 174,406 & 7.3 & 223,214 & 8.3 & 27.99 & 48,808 & 25.89 & 45,148 & 219,554 \\
\hline $\begin{array}{lr}\text { Other } & \text { Services } \\
\text { (except Public } \\
\text { Administration) }\end{array}$ & 144,189 & 6.0 & 166,974 & 6.2 & 15.80 & 22,785 & 14.15 & 20,408 & 164,597 \\
\hline $\begin{array}{l}\text { Federal } \\
\text { Civilian }\end{array}$ & 34,059 & 1.4 & 31,067 & 1.2 & -8.78 & $-2,992$ & 2.47 & 843 & 34,902 \\
\hline Military & 39,275 & 1.6 & 33,652 & 1.2 & -14.32 & $-5,623$ & -4.79 & $-1,880$ & 37,395 \\
\hline $\begin{array}{l}\text { State } \\
\text { Government }\end{array}$ & 114,666 & 4.8 & 79,782 & 3.0 & -30.42 & $-34,884$ & 4.19 & 4,810 & 119,476 \\
\hline $\begin{array}{l}\text { Local } \\
\text { Government }\end{array}$ & 218,954 & 9.1 & 213,030 & 7.9 & -2.71 & $-5,924$ & 2.85 & 6,240 & 225,194 \\
\hline $\begin{array}{l}\text { Total } \\
\text { Employment }\end{array}$ & $2,397,386$ & 100.0 & $2,697,447$ & 100.0 & 12.52 & 300,061 & 14.74 & 353,415 & $2,750,801$ \\
\hline
\end{tabular}


Table 2. Employment Rate Change of Employment in LA Leading Sectors From 2005-2017

\begin{tabular}{l|c|c}
\hline & National & Louisiana \\
\hline $\begin{array}{l}\text { Health Care and Social } \\
\text { Assistance }\end{array}$ & $34.85 \%$ & $30.93 \%$ \\
\hline Retail Trade & $4.7 \%$ & $7.08 \%$ \\
\hline $\begin{array}{l}\text { Accommodation and Food } \\
\text { Services }\end{array}$ & $28.16 \%$ & $27.99 \%$ \\
\hline Local Government & $3.81 \%$ & $-2.71 \%$ \\
\hline Construction & $-2.06 \%$ & $17.74 \%$ \\
\hline $\begin{array}{l}\text { Other Services (except Public } \\
\text { Administration) }\end{array}$ & $16.39 \%$ & $15.80 \%$ \\
\hline $\begin{array}{l}\text { Administrative and Waste } \\
\text { Services }\end{array}$ & $16.34 \%$ & $16.30 \%$ \\
\hline Manufacturing & $-9.12 \%$ & $-7.51 \%$ \\
\hline $\begin{array}{l}\text { Professional, Scientific, and } \\
\text { Technical Services }\end{array}$ & $26.66 \%$ & $25.21 \%$ \\
\hline $\begin{array}{l}\text { Real Estate and Rental and } \\
\text { Leasing }\end{array}$ & & $46.03 \%$ \\
\hline
\end{tabular}

The National Growth component calibrates the increase in Louisiana employment that may be credited to the comprehensive national economic context and industry trends. If the sector structure and circumstances of employment were uniform locally and nationally, then Louisiana's progress in employment gains over 2005-2017 would have been in sync with the overall national growth rate of 13.81 percent. Concerning Louisiana, the national growth component is positive in all sectors (Table 3). However, Louisiana's 12.52 percent employment increase, as seen in Table 1, fell short of the nation's overall 13.81 percent employment growth due to its inability to match the nation's conditions and structure in thriving sectors. Specifically, it would have been economically advantageous for Louisiana to develop an environment that supports leading non-farm sectors (Table 3). Hence, the state could have possibly experienced employment gains in those sectors.

The industry mix component sets out to answer the following query: "Did Louisiana's employment increase of 12.52 percent lag the overall US rate of 13.81 percent due to more concentrated employment in slower growing industries when compared to the country as a whole?" A positive industrial mix implies that the employment in each sector at the local, or regional level is increasing at a higher rate than a country's economy. And if the opposite is the case, that sector is expanding employment at a slower rate compared to a country's economy. Table 3 illustrates that the Louisiana farm industry has a negative industrial mix; thus, demonstrating a dimmer growth percentage juxtaposed to the US overall employment growth. Additionally, multiple sectors including Forestry, Fishing, and Related Activities; Construction; Manufacturing; Wholesale Trade; Retail Trade; Military; State Government; Local Government; and Information show a negative industrial mix, indicating that Louisiana employment, in these sectors, is slow growing US sectors (Table 3). However, other sectors display a positive industrial mix suggesting faster employment expansion in each area. That is, the sectors of Finance and Insurance; Real Estate and Rental and Leasing; Accommodation and Food Services; Professional, Scientific, and Technical Services; Utilities; Administrative and Waste Services; and Other Services (except Public Administration) exhibited a positive industrial mix. Therefore, employment in the aforesaid State sectors are growing at a faster rate than in the US (Table 3). Also, these data point out that the sectors of Management of Companies and Enterprises; Mining; Transportation and Warehouse; Educational Services; Health Care and Social Assistance; Arts, Entertainment, and Recreation have greatly contributed to employment growth in Louisiana from 2005 to 2017 (Table 3).

A Regional Shift or Competitive effect is the difference between the actual change in employment and the employment change to be expected if each industrial sector grew at the national rate. If a positive effect is indicated in a sector, the State economy has been effective in 
drawing investment to a given industry. A positive value helps indicate whether a given region, or state holds a comparative advantage in a sector. Specifically, a positive regional, or state share in tandem with a positive industrial mix indicate a probable comparative advantage in that sector. A negative competitive effect conveys that the regional, or state economy has been overcome by other states, or regions in terms of employment growth. According to Table 3, sectors including Mining; Forestry, Fishing, and Related Activities; Utilities; Wholesale Trade; Transportation and Warehousing; Information; Professional, Scientific, and Technical Services; Management of Companies and Enterprises; Arts, Entertainment and Recreation; Military; State Government; and Local Government display negative competitive effects. The positive industry mix and competitive effect of Finance and Insurance; Real Estate and Rental and Leasing; Administrative and Waste Services; Educational Services; Accommodation and Food Services; Other Services (except for Public Administration) indicate their comparative advantage in economic growth in Louisiana. So, these data indicate that Louisiana has been losing jobs in more sectors than they have gained jobs. That is, the state has not been successful in attracting, or maintaining a high level of new employment (Table 3).

The total expansion of employment in twelve years (2005-2017) is 300,061 in Louisiana as explained in Table 1 above. The lack of employment growth in multiple sectors, especially strong economic sectors like Forestry, Fishing, and Related Activities, is likely due to the state prioritizing other sectors. Consequently, the less prioritized sectors do not show a comparative advantage in Louisiana's economic growth. However, it appears that the focus on niche economic investment in subsectors like lumber, furniture, and pulp and paper within the forest industry will enable the capacity for some economic growth.

The Real Estate and Rental and Leasing sector is the third leading sector in employment growth displaying potential for gains in employment. The Real Estate and Rental and Leasing sector has created 37,905 new jobs in the Louisiana economy from 2005 to 2017 (Table 1). The Real Estate and Rental and Leasing industry includes but is not limited to "insurance companies, developers, realtors, selling, renting and/or buying real estate for others, appraising real estate, real estate lessors industries (including equity real estate investment trusts (REITs)); equipment lessors industries (including motor vehicles, computers, and consumer goods); and lessors of nonfinancial intangible assets (except copyrighted works)" (Bureau of Labor Statistics, 2019). The Real Estate and Rental and Leasing has made up 46 percent of the actual employment growth in Louisiana from 2005 to 2017. The combination of the industrial mix and the competitive effect in this sector points to it having the largest comparative advantage in Louisiana. Thus, policymakers and other stakeholders should prioritize investment plans for this segment of the business sector. Prioritizing fiscal effort in this area would likely contribute to affecting poverty issues in Louisiana.

On the other hand, manufacturing, one of the top five employers in the state of Louisiana indicate negative influences on actual employment expansion from 2005 to 2017. The manufacturing sector reports 11,819 actual employment losses over the last twelve years, suggesting that investment in the manufacturing industry may be counterproductive to expedient economic growth in Louisiana. The diminishing employment drift in the last twelve years say that manufacturing is no longer one of the major contributors to economic growth in the state. According to Louisiana Economic Development (2017), at least 90 percent of incentives or investments are directed toward small businesses development in the form of small business development centers, state trade expansion programs, zoning programs, industrial tax exempt programs, small business loans, tax incentive programs, small business bonding programs, small and emerging business development programs, which play a primary part in the employment growth of Louisiana. Extending these provisions to the sectors that 
show a comparative advantage, namely Finance and Insurance; Real Estate and Rental and Leasing; Administrative and Waste Services; Educational Services; Accommodation and Food Services; and Other Services (except Public Administration) can produce fast and consistent economic returns. Had Louisiana prioritized Comparative areas from 2005 to 2017, current employment growth would be higher today. 
Table 3: Shift-Share Components, 2005-2017

\begin{tabular}{|c|c|c|c|c|c|c|c|c|}
\hline & \multicolumn{2}{|c|}{ Location Quotient ${ }^{4}$} & \multicolumn{2}{|c|}{ National Growth ${ }^{5}$} & \multicolumn{2}{|c|}{ Industry $\mathrm{Mix}^{6}$} & \multicolumn{2}{|c|}{ Region Shift ${ }^{7}$} \\
\hline Major Industry & 2005 & 2017 & Percent & Net & Percent & Net & Percent & Net \\
\hline Farm Employment & 0.81 & 0.87 & 13.81 & 4,142 & -14.75 & $-4,424$ & 6.41 & 1,922 \\
\hline $\begin{array}{lr}\text { Forestry, } & \text { Fishing, } \\
\text { and } & \text { Related } \\
\text { Activities } & \\
\end{array}$ & 1.62 & 1.46 & 13.81 & 2,577 & -2.11 & -394 & -12.14 & $-2,266$ \\
\hline Mining & 4.49 & 3.34 & 13.81 & 7,183 & 67.47 & 35,100 & -48.05 & $-24,997$ \\
\hline Utilities & 1.25 & 1.06 & 13.81 & 1,371 & 2.62 & 260 & -18.60 & $-1,846$ \\
\hline Construction & 1.15 & 1.41 & 13.81 & 24,208 & -16.83 & $-29,504$ & 20.76 & 36,404 \\
\hline Manufacturing & 0.77 & 0.80 & 13.81 & 21,742 & -23.45 & $-36,923$ & 2.13 & 3,362 \\
\hline Wholesale Trade & 0.90 & 0.85 & 13.81 & 10,967 & -11.53 & $-9,157$ & -6.50 & $-5,162$ \\
\hline Retail Trade & 1.00 & 1.05 & 13.81 & 35,910 & -10.83 & $-28,157$ & 4.10 & 10,656 \\
\hline $\begin{array}{l}\text { Transportation } \\
\text { and Warehousing }\end{array}$ & 1.15 & 0.98 & 13.81 & 12,383 & 22.99 & 20,621 & -21.13 & $-18,953$ \\
\hline Information & 0.69 & 0.62 & 13.81 & 4,719 & -18.81 & $-6,430$ & -10.32 & $-3,526$ \\
\hline $\begin{array}{ll}\text { Finance } & \text { and } \\
\text { Insurance } & \end{array}$ & 0.74 & 0.77 & 13.81 & 11,689 & 14.38 & 12,172 & 3.00 & 2,536 \\
\hline $\begin{array}{ll}\text { Real Estate } & \text { and } \\
\text { Rental } & \text { and } \\
\text { Leasing } & \\
\end{array}$ & 0.83 & 0.96 & 13.81 & 11,370 & 14.28 & 11,762 & 17.94 & 14,773 \\
\hline $\begin{array}{l}\text { Professional, } \\
\text { Scientific, and } \\
\text { Technical } \\
\text { Services }\end{array}$ & 0.75 & 0.76 & 13.81 & 15,723 & 11.82 & 13,461 & -0.41 & -469 \\
\hline $\begin{array}{lr}\text { Management } & \text { of } \\
\text { Companies } & \text { and } \\
\text { Enterprises } & \end{array}$ & 0.89 & 0.83 & 13.81 & 3,184 & 29.59 & 6,822 & -11.22 & $-2,588$ \\
\hline $\begin{array}{l}\text { Administrative } \\
\text { and } \quad \text { Waste } \\
\text { Services }\end{array}$ & 0.90 & 0.91 & 13.81 & 18,027 & 2.39 & 3,121 & 0.11 & 138 \\
\hline $\begin{array}{l}\text { Educational } \\
\text { Services }\end{array}$ & 0.83 & 0.87 & 13.81 & 5,653 & 19.25 & 7,881 & 3.70 & 1,514 \\
\hline $\begin{array}{l}\text { Health Care and } \\
\text { Social Assistance }\end{array}$ & 1.03 & 1.03 & 13.81 & 33,197 & 18.06 & 43,422 & -0.93 & $-2,247$ \\
\hline $\begin{array}{l}\text { Arts, } \\
\text { Entertainment, } \\
\text { and Recreation }\end{array}$ & 1.02 & 0.88 & 13.81 & 6,775 & 15.07 & 7,393 & -18.76 & $-9,206$ \\
\hline $\begin{array}{l}\text { Accommodation } \\
\text { and Food Services }\end{array}$ & 1.07 & 1.10 & 13.81 & 24,079 & 12.08 & 21,069 & 2.10 & 3,660 \\
\hline $\begin{array}{lr}\text { Other } & \text { Services } \\
\text { (except } & \text { Public } \\
\text { Administration) }\end{array}$ & 1.06 & 1.09 & 13.81 & 19,907 & 0.35 & 500 & 1.65 & 2,377 \\
\hline Federal Civilian & 0.88 & 0.79 & 13.81 & 4,702 & -11.33 & $-3,859$ & -11.26 & $-3,835$ \\
\hline Military & 1.39 & 1.27 & 13.81 & 5,422 & -18.59 & $-7,303$ & -9.53 & $-3,743$ \\
\hline State Government & 1.60 & 1.08 & 13.81 & 15,831 & -9.61 & $-11,021$ & -34.62 & $-39,94$ \\
\hline Local Government & 1.14 & 1.09 & 13.81 & 30,230 & -10.96 & $-23,989$ & -5.56 & $-12,164$ \\
\hline $\begin{array}{l}\text { Total } \\
\text { Employment }\end{array}$ & 1.00 & 1.00 & 13.81 & 330,994 & 0.94 & 22,421 & -2.23 & $-53,354$ \\
\hline
\end{tabular}

\section{SUMMARY OF RESULTS AND POLICY IMPLICATIONS}

This paper serves to illuminate employment shifts in multiple sectors of Louisiana's economy, which enables more efficient investment in industry that indicate a comparative advantage in the region. Overall, these data illustrate that Louisiana has experienced a progressive employment rate even though it has not kept pace with employment growth at the national level. These results suggest that economic policy alternatives should be directed at navigating the State's economic development away from low growth sectors. Employment expansion of the manufacturing sector has diminished over the last twelve years by 7.5 percent, even 
though the sector is responsible for 5 percent $(145,000)$ of the employment in Louisiana. Thus, manufacturing is not the pillar of growth that is so popularly communicated to the state and country. Additionally, the future of employment growth of the manufacturing sector is minimal, as it holds no comparative advantage in the region. However, it would be economically advantageous to adopt efficient manufacturing employment policy alternatives that support blue collar workers, as forestry endures as the leading source of revenue in the state (Louisiana Division of Administration, 2019). Particularly, it is important to maintain a labor force that possess the skills to refine and produce lumber, furniture and paper products. Comparative advantages are seen in the following areas: Finance and Insurance; Real Estate and Rental and Leasing; Administrative and Waste Services; Educational Services; Accommodation and Food Services; and Other Services (except for Public Administration). Policy alternatives that seek to enhance the development of these sectors would enable the state to realize a hyper expansion of employment in these areas of the economy. Thus, program initiatives directed at those specific sectors, with enough infrastructure, would enhance the economic development of Louisiana. It is plausible to believe that improved economic growth would draw new investors to Louisiana. The existence of sectors indicating a negative comparative advantage cannot be ignored. It implies that these declining sectors have lost employment to other state economies. While Manufacturing, Wholesale Trade, and Local Government make up a combined 16.1 percent of employment in Louisiana, substantial employment losses hint that continued reliance on these sectors would threaten the vitality of Louisiana's economy. Nevertheless, policymakers should endeavor to revitalize these sectors, as they remain vital to budgetary impacts. Additionally, it is important that policymakers at every level consistently conduct econometric evaluations to better determine policy priorities. Lastly, policymakers must seek partners that demonstrate congruent goals and the ability to augment local and state budgets.

\section{References}

Al-Anzi, N. (2009). Workplace environment and its impact on employee performance. (A Thesis Submitted in partial fulfilment of the Requirements for the Degree of Master of Business Administration). University of Malaysia, Bahrain.

Barff, R. A. and Knight III, P. L. (1988). “Dynamic Shift-Share Analysis”, Growth and Change, vol. 19, pp. 2-10.

Bendavid-Val, Avrom. "Relative Regional Industrial Composition Analysis." Chapter 5. Regional and Local Economic Analysis for Practitioners, New York: Praeger Publishers, 1983

Brown, H.J. (1969). 'Shift and share projections of regional economic growth: an empirical test'. Journal of Regional Science, 9(1). pp. 1-18.

Cangiano, A. (2014). Migration policies and migrant employment outcomes: Conceptual analysis and comparative evidence for Europe. Comparative migration studies, 2(4).

Card, D., Kluve, J. and Weber, A. (2010): “Active Labour Market Policy Evaluations: A Meta Analysis*,” The Economic Journal, 120(548), 452 -477.

Hustedde, R., Shaffer, R. and Pulve, G, (1983). Community Economic Analysis: A How-To Manual. North Central Regional Center for Economic Development, Iowa State University, Ames, Iowa.

Knudsen, D.C. (2000) 'Shift-share analysis: further examination of models for the description of economic change'. Socio-Economic Planning Sciences, 34(3). pp. 177-98.

Lapping, M.B. (2006). “Community Economics: Linking Theory and Practice, edited by Ron Shaffer, Steve Deller, and Dave Marcouiller," Journal of Regional Science, Wiley Blackwell, vol. 46 (4). pp. 805-806, October.

Loayza, N., Olaberría E., Rigolini, J. and Christiaensen, L. (2009). Natural Disasters and Medium-Term Economic Growth: The Contrasting Effects of Different Events on Disaggregated Output. Mimeo, The World Bank.

Martin, J. P. (2014). Activation and Active Labour Market Policies in OECD Countries: Stylized Facts and Evidence on Their Effectiveness. UCD Geary Institute Discussion Paper Series 2014/09. Dublin:.IZA Policy Paper Series No. 84. Dublin: Geary Institute, University College Dublin. 
Melachroinos, K. (2002). European Integration and the Spatial Dynamics of Manufacturing Employment Change. Environment and Planning A: Economy and Space, 34 (11). pp. 2017-2036.

Ortiz, M. (2016). Louisiana Tourism Forecast. University of New Orleans Research Center. Pestel, N. (2014). Employment effects of green energy policies. IZA World of Labor 2014: 76 doi: 10.15185/izawol.76.

Public Act 2015 70. Health and Safety at Work Act of 2015. New Zealand. http://www.legislation.govt.nz/act/public/2015/0070/latest/DLM5976660.html

Regional Income Division, Bureau of Economic Analysis (2019). United States. Suitland, M.D. https://apps.bea.gov/itable/iTable.cfm?ReqID=70\&step=1

Reyneri E. and Fullin G. (2011). "Labour Market Penalties of New Immigrants in New and Old Receiving West European Countries". International Migration, 49(1): 31-57.

Rueda, D. (2006). Social Democracy and Active Labour-Market Policies: Insiders, Outsiders and the Politics of Employment Promotion. B.J.Pol.S. 36, 385-406.

State of Louisiana, Louisiana Division of Administration (2019). Baton Rouge, Louisiana. https://www.doa.la.gov/Pages/default.aspx

State of Louisiana, Louisiana Economic Development (LED) (2017). 2017 Annual Program \& Incentives performance Report. Baton Rouge, Louisiana.

Toshkov D. and De Haan L. (2013). "The Europeanization of Asylum Policy: An assessment of the EU impact on asylum applications and recognitions rates". Journal of European Public Policy, 20 (5): 661-683

U.S. Department of Agriculture, Economic Research Service (2019). United States. Washington, D.C. https://data.ers.usda.gov/reports.aspx?StateFIPS=22\&StateName=Louisiana\&ID=17854

U.S. Department of Commerce, Bureau of Census (2018). United States. Washington, D.C. https://www.census.gov/quickfacts/fact/table/LA/IPE120217

U.S. Department of Labor, Bureau of Labor Statistics (2005 \& 2019). United States.Washington, D.C. https://www.bls.gov/bls/news-release/laus.htm\#2005

U.S. Department of Labor, Bureau of Labor Statistics (2019). About the Real Estate and Rental and Leasing sector. United States. Washington, D.C. https://www.bls.gov/iag/tgs/iag53.htm

Van Vliet, O. and Koster, F. (2011). Europeanization and the Political Economy of Active Labour Market Policies. European Union Politics, 12(2), 217-239. 